\title{
A NEW SPECIES OF CECROPIA (MORACEAE)
}

\author{
C. C. BERG \\ Instituut voor Systematische Plantkunde, Utrecht
}

Cecropia silvae C. C. Berg nov. spec.

Arbor 25-30 m alta. Ramuli foliosi hispidi, hispiduli, vel scabri. Lamina fere ad petiolum 15-partita; segmenta oblanceolata, 7-25 cm longa, $2-4.5 \mathrm{~cm}$ lata, plerumque obtusa, pagina superiore scabridula, inferiore arachnoideo-tomentosa, ad venas albo-puberula vel -hirtella; venae secundariae circ. $20-40$-jugae, maxime $0.5 \mathrm{~cm}$ inter se remotae; petiolus arachnoideo-tomentellus atque etiam hirtellus, sed basi apiceque hirsutus vel hispidus; pulvinus pilis brunneis pluricellularibus, longioribus albis unicellularibus, obsitus. Inflorescentiae pistillatae pedunculo 6-7 cm longo; spicae 4, 8-9 cm longae.

Tree up to $25-30 \mathrm{~m}$ tall. Leafy twigs hispid to hispidulous to scabrous by mainly uncinate hairs of different length. Leaves subrotundate to broadly ovate, 15 (or more than 15?) -parted to $0.5-1 \mathrm{~cm}$ from the petiole, segments oblanceolate, 7-25 cm long, $2-4.5 \mathrm{~cm}$ broad, mostly obtuse, sometimes subacute to subacuminate, above scabridulous by short rigid hairs of different length, sparsely intermixed with longer weaker hairs and brown pluricellular hairs, beneath arachnoid-tomentose, this indument disappearing from the main veins with age, on the veins whitish puberulous to hirtellous, the hairs distinctly different in length, the longer ones mostly uncinate; c. $20-40$ pairs of secondary veins, at most $0.5 \mathrm{~cm}$ from each other; petioles $35-47 \mathrm{~cm}$ long, arachnoidtomentellous and sparsely to rather densely hirtellous, but hirsute to hispid at the upper and the lower end; pulvinus with brown pluricellular hairs and longer white unicellular hairs.

Pistillate inflorescence with a 6-7 cm long, hirtellous to scabrous and towards the apex hirsute to hispid peduncle; spikes $4,8-9 \mathrm{~cm}$ long, c. $9 \mathrm{~mm}$ in diameter, the rachis with up to $2 \mathrm{~mm}$ long stiff white hairs, the perianth c. $3 \mathrm{~mm}$ high, towards the apex densely arachnoid-tomentose.

Type: N. T. Silva 956 ㅇ, Brazil, Pará, Rio Jarí, Monte Dourado (U).

Paratype: F. H. F. Oldenburger, R. Norde \& J. P. Schulz 1112 sterile, Suriname, Sipaliwini savanna area near Brazilian frontier, in high forest (U).

Unfortunately the material is rather poor; the stipule and the spathe are lacking. Nevertheless it is distinct enough for describing a new species. This species resembles $C$. angustifolia Trécul in the number and the shape of the leaf segments, and $C$. ulei Snethlage in the number of leaf segments. It differs distinctly from the two species in the indument, and from the latter also in the venation and the shape of the leaf segments. 


\section{ACKNOWLEDGEMENTS}

The author is indebted to Dr. J. Cuatrecasas for his comment on the specimens described, and to Dr. K. U. Kramer for the Latin diagnosis. 